\title{
Development of Natural Science Learning Media in Primary School Using Flash Applications to Increase Student's Achievement
}

\author{
Hindayati Mustafidah, ${ }^{1, *}$, Muhammad Gilang Audi Imani ${ }^{1}$, Sriyanto $^{2}$, and Suwarsito ${ }^{2}$ \\ ${ }^{1}$ Faculty of Engineering - Universitas Muhammadiyah Purwokerto, J1. Raya Dukuhwaluh Purwokerto, Central Java, Indonesia 53182 \\ ${ }^{2}$ Faculty of Education - Universitas Muhammadiyah Purwokerto, Jl. Raya Dukuhwaluh Purwokerto, Central Java, Indonesia 53182
}

\begin{abstract}
The negative impact of the development of information technology in the form of smartphones triggers students lazy to learn. But the positive impact can increase student activity and learning achievement because students can play while learning. This was experienced by students of Qaryah Thayyibah Elementary School in Purwokerto, Indonesia. In the process of teaching and learning at the elementary school is still using books so that students' interest in learning is lacking, especially science subjects. But on the other hand, students really like playing with their smartphones. This is the reason for doing research on the development of Android-based learning media using the Flash application. The method used in conducting this research is the Multimedia Development Life Cycle (MDLC). The development of this multimedia method is carried out based on six stages, namely concept, design, collecting material, assembly, testing, and distribution. Based on the results of testing on students, using flash applications in science subjects can provide solutions to optimize student learning processes. This is evidenced by the increase in student scores by $7.275 \%$, namely before using the application has an average value of $7.56 \pm 0.726$ and after using the learning media application increased to $8.11 \pm 0.821$.
\end{abstract}

\section{Introduction}

Widespread use and dependence of information technology in the wider community is undeniably giving rise to concerns among various circles, including educators and parents. Many teachers and parents worry that the widespread use of communication and information technology can have an adverse impact on children. Some things that seem to be very much a concern for parents are the possibility of children easily accessing various pornographic or porno actions, as well as the effects of addiction on social media and games, especially online games. This impact will certainly interfere with the concentration of children's learning, and later make children more happy to be alone so that their social sensitivity develops is not optimal.

Learning in schools today still tends to be monotonous, where learning is not yet student-centered. Although the government has launched scientific learning with the enactment of the 2013 Curriculum, in reality the learning applied in several schools is still relatively monotonous, with teacher-centeredness. This learning model does not prioritize action on students but more on the lecture process conducted by the teacher while students listen passively. As an example of a case in Qaryah Thayyibah Purwokerto Elementary School (SD QITA), information was obtained that many students felt easily bored with the amount of material, as well as difficult terms that needed to be memorized in science lessons. Teachers feel they must always find new strategies so that their students are not bored, and more motivated to learn. On the other hand, parents and teachers are also worried about their children's interest in smartphones. Based on interviews with several parents, it was obtained data that children tend to be difficult to be asked to study at home. They are much more enthusiastic about picking up gadgets, especially smartphones, rather than to reading books or notebooks.

Based on the reasons that have been conveyed, it takes an alternative problem solving that can facilitate children's needs for communication and information technology, as well as being a means of active and interactive learning activities that are not monotonous. Therefore, a learning media based on communication and information technology is built, which can be used as a learning tool at home, so that children do not monotonically learn only by memorizing through textbooks. In this media contains materials and exercises about science subjects in class III elementary school chapter 1 through chapter 5 .

Media is an intermediary or messenger from the sender to the recipient of the message. Media can be human, material, or events that build conditions that make students able to acquire knowledge, skills, or attitudes [1]. Learning media is a means to establish communication interactions that are educational between teachers and students [2] as well as channeling messages 
or content, stimulating students' thoughts, feelings, attention and abilities, so as to encourage teaching and learning [3-4]. The learning media in question are books, tape recorders, cassettes, video cameras, video recorders, films, slides (pictures), photos, pictures, graphics, television and computers. This is a form of implementation of the contents of Law RI No.20 of 2003 which states that learning is the process of interaction of students with educators and learning resources in a learning environment. Information technology-based learning media can be applied with tutorial, simulation, and games models, including the use of the internet in it as a medium of knowledge transfer from one device to another or transfer of information between media [5] and [6].

Some advantages of ICT integration in the learning process are suggested by [7], [8], [9]. This is evidenced by several results of research conducted by [10] who developed Adobe Flash CS5-based science learning media and showed that there was a significant increase in the quality of learning seen from the responses of students and teachers' interests. Another study of learning media development was conducted by [11] which showed an increase in learning motivation for students of Grade 5 of the Dagen 1 Public Elementary School in Jaten. Mobile multimedia had been developed by [12] to present of descriptive studies showed an increase in the ability to understand colors and letters in class 1 elementary school students, and [13] aimed at testing the impact of use multimedia program with Adobe Flash, achieving results of increasing student academic achievement.

Long before ICTs developed as they are today, ICTbased learning media can also improve students' understanding in reading the Qur'an [14]. In addition, the improvement of understanding and achievement of junior high school students and university students can also be enhanced by ICT-based learning media [15], [16], [17], [18]. Other research is to implement multimedia applications with animated cartoons on science learning in elementary schools, which results in an increase in student interest [19].

\section{Method}

\subsection{Data Collection}

This application in the form of learning media was built using AdobeFlash CS6 software with Actionscrip 3.0 programming language for grade III elementary school science materials. The research data was collected from interviews with teachers related to the curriculum, observation to find out the learning activities that took place in Purwokerto QITA Elementary School and how the teacher delivered the material and the things students did during the learning process, and the third grade elementary science material documentation.

\subsection{System Engineering}

The application was designed using the Multimedia Development Life Cycle (MDLC) model as shown in Fig. 1.

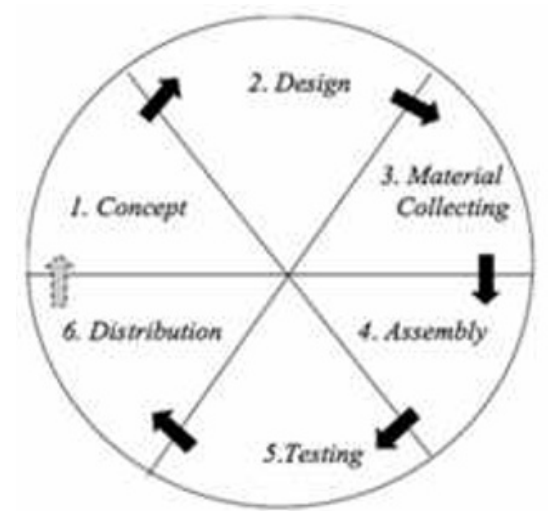

Fig. 1. SDLC Model for Application Development [20].

Concept. The concept stage is the stage to determine the goals and who will use the application. At this stage it is designed as to what this application will be made.

Design. The design phase is the stage of making specifications regarding the program architecture, appearance and material requirements for the program. The hardware requirements needed for the implementation of this application are a set of computers and an Android Mobile unit. This learning media is built based on applications with the Android operating system that is open source and runs on mobile devices that are commonly used by the public with various advantages [21], [22], [23]. Software requirements needed for the implementation of this application are Adobe Flash CS6, Adobe Photoshop CS6, Flash Player, and Adobe AIR. Application design is used by Unified Modeling Language (UML) with use case diagrams and activity diagrams. As the main media development software, Adobe Photoshop as an image editor software is devoted to photo/image editing and effect making [24] and Macromedia Flash to produce interactive, interesting and dynamic presentations and movie games and various other advantages [12], [25], [26]. Action script as an Adobe Flash programming language is used to create animations or interactions [27]. Unifield Modeling Language (UML) is used for the purposes of visualizing, designing and documenting the system [28]. Use case diagrams and activity diagrams are used to find out what functions are in the system and who has the right to use these functions, as well as describing the various flow of activities in the system [29]. Activity diagrams and use case diagrams are presented in Fig. 2, 3, 4 and 5.

Material Collecting is a process for collecting data in the form of material presented in an application, multimedia files such as audio and images needed in multimedia presentation.

Assembly. This stage is the conversion phase of the design into the form of program code that can be understood by the machine. The encoding is done using Actionscript 3.0.

Testing. This phase includes the overall testing of applications that have been built using the Black Box Testing Method [30]. 
Distribution. At this stage, the application is processed into an *.apk file. After becoming an *.apk file, this application is ready to be published for users.

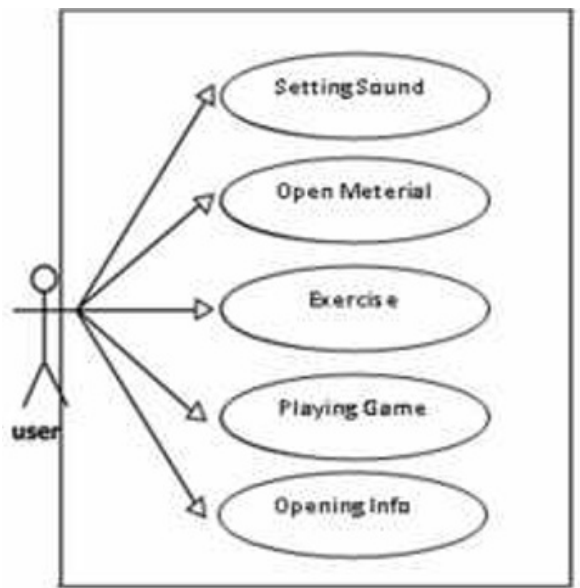

Fig. 2. SDLC Model for Application Development

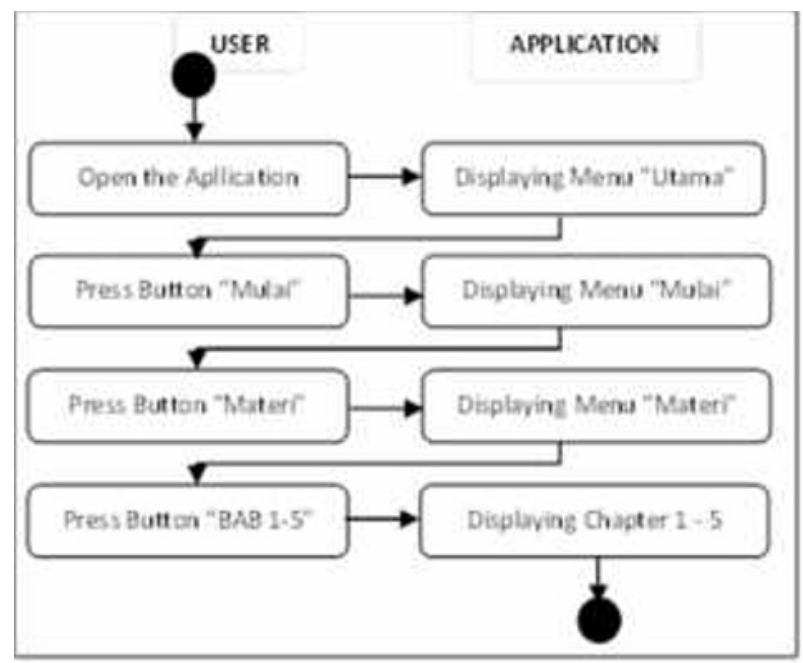

Fig. 3. Activity Diagram Displaying Material for Elementary School Science in the Third Grade

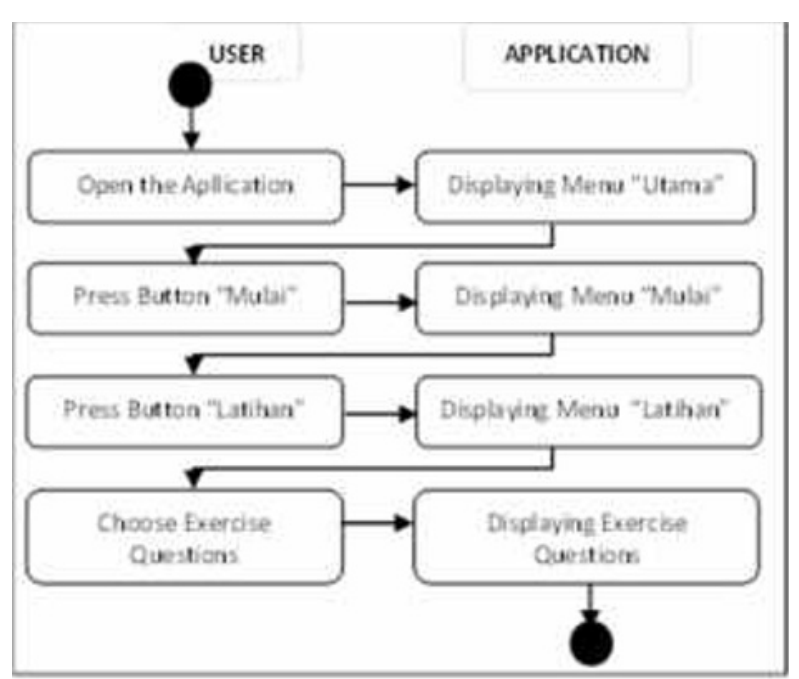

Fig. 4. Activity Diagram Showing Exercise

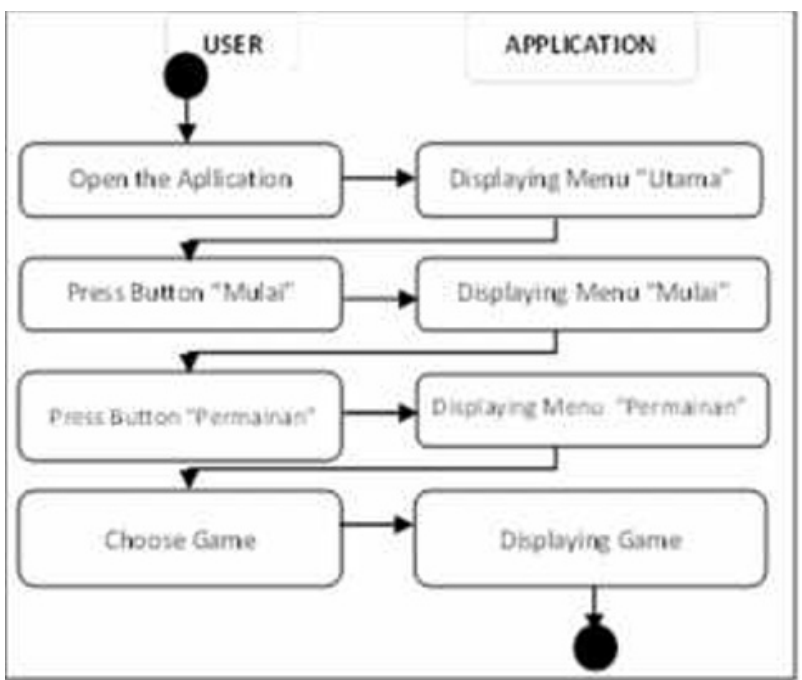

Fig. 5. Activity Diagram Showing the Game

\subsection{Measurement of Student Learning Achievement}

Measurement of student achievement scores is done before and after using the application. Measurements were carried out by testing applications that had been developed for third grade students at QITA Elementary School as research samples.

\section{RESULTS AND DISCUSSION}

\subsection{Learning Media Application}

The learning media application produced from this study is a .apk file with version 1.0 that is ready to run on smartphone devices based on the Android operating system. This application contains third grade elementary school science materials with interesting animations and pictures to improve student learning interest, and make students easier to understand the material presented. The material presented is chapter 1 to chapter 5 or the same as the implementation of learning in 1 semester. In this learning media there is also a practice question that can be used as an ability test tool for students. The problem consists of 10 items with 3 minutes working time. After students work on the questions, the application will immediately display the scores obtained by students. This application is also equipped with discussion of questions and answer keys.

The learning media application produced consists of several menus, namely the "Utama", "Mulai", "Materi", "Soal", and "Permainan" menus. Menu "Utama" is the main menu that first appears when the application is run. There are 3 buttons on the main menu, namely Enter ("Masuk"), Sound, Info (Fig. 6). The Enter button serves to display the 4 core sub menus of this application namely Material, Exercise, Games, and Exit. Sound button functions to activate and deactivate music. The info button contains the function of the third grade science teaching learning media for elementary school in 1 semester. 


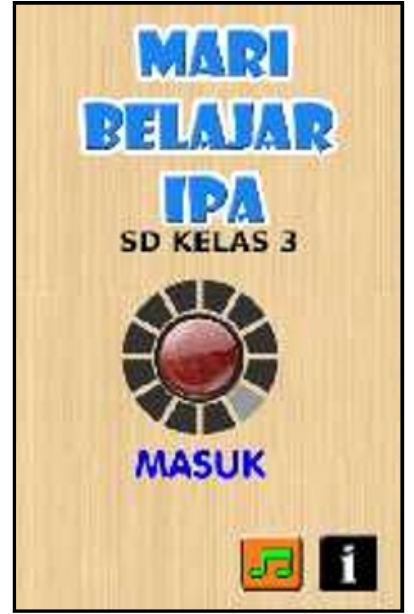

Fig. 6. Main Menu of the Third Class Natural Science Learning Application

The Start menu has 4 menus where each menu has its own function (Fig. 7). Menu Material contains 5 CHAPTER menus on the subject matter of grade III science subjects. The Problem menu contains a menu of practice questions for each chapter. Menu Games contain various games according to the material presented.

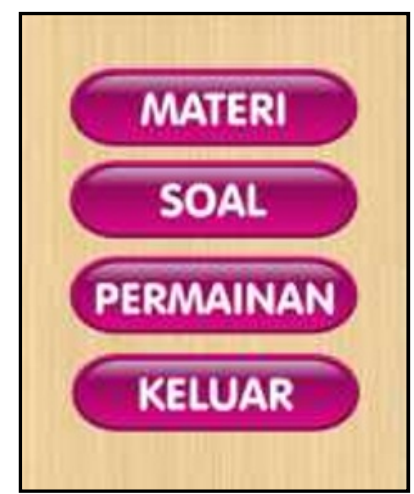

Fig. 7. Start Menu Interface

The "MATERI" menu is included in the main menu, in which there are $5 \mathrm{BAB}$ menus, and includes the Home menu to return to the Start menu. The chapter menu contains class III science subjects in accordance with the existing chapter (Fig. 8).

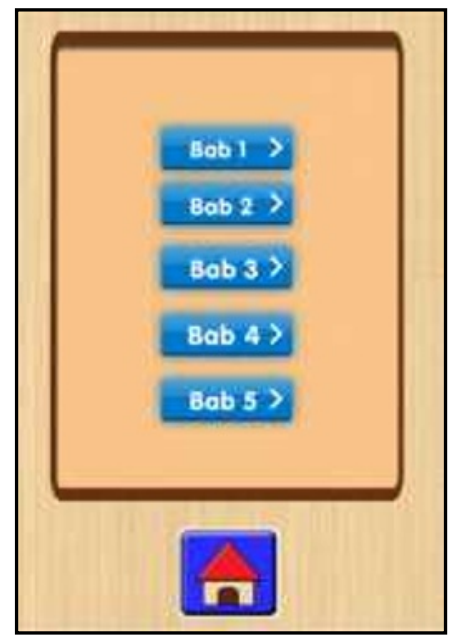

Fig. 8. Menu "MATERI" Interface
Fig. 8 is a view that appears on the Material menu. If the user presses CHAPTER 1 button, it will display the material about CHAPTER 1 (Fig. 9), the CHAPTER 2 button will display CHAPTER 2 material (Fig. 10), and so on until CHAPTER 5.

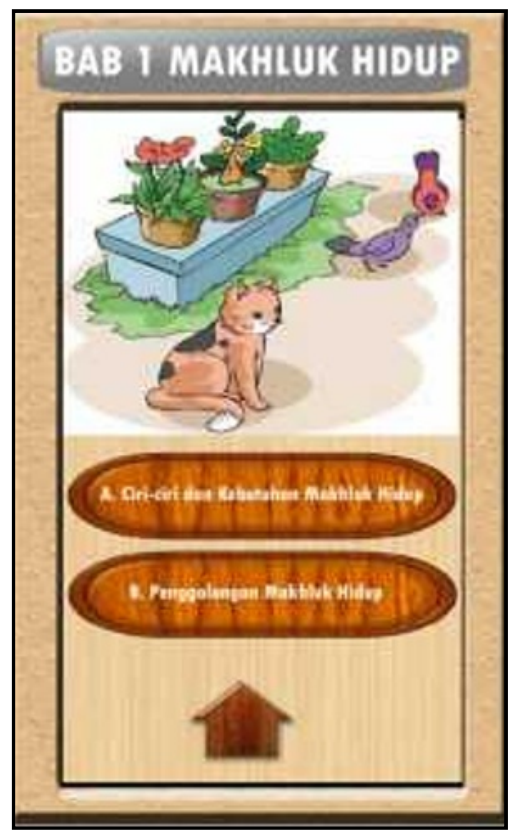

Fig. 9. CHAPTER 1 Interface on the MATERI Menu

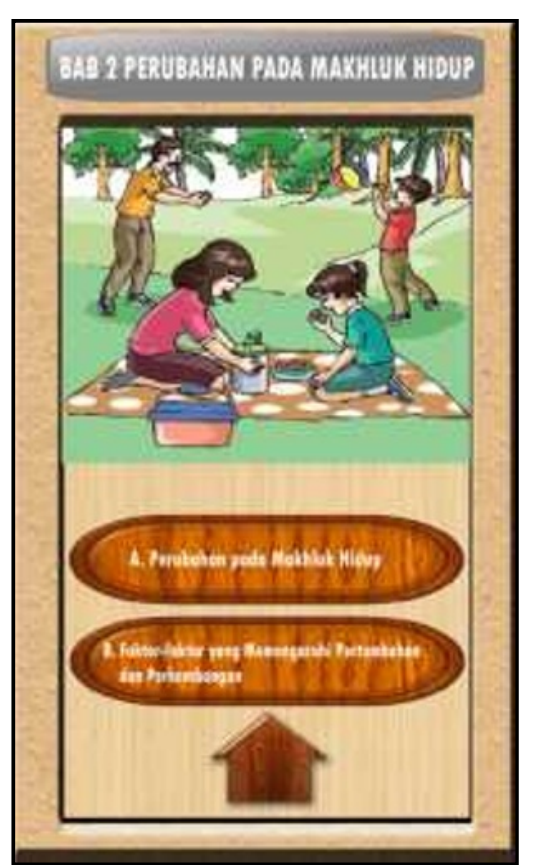

Fig. 10. CHAPTER 2 Interface on the MATERI Menu

The Question menu is included in the main menu, in which there is a sub menu of practice questions from CHAPTER 1- 5. The following is a menu display of the questions (Fig. 11). If the user presses one of the submenu buttons on the question menu, a new display will appear containing an explanation of how to do the practice question (Fig. 12). 


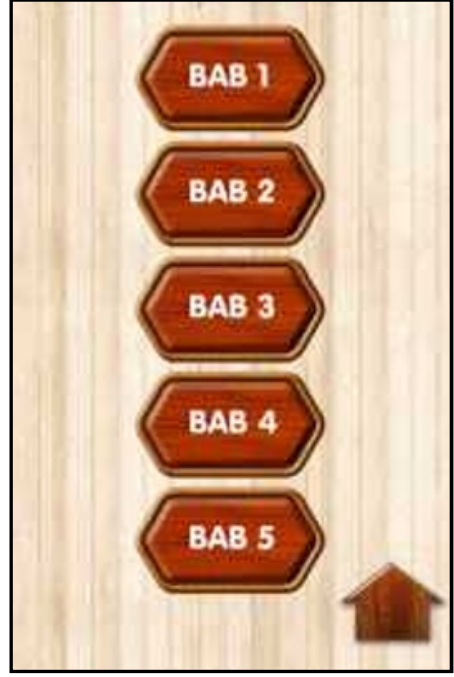

Fig. 11. Interface Question Menu

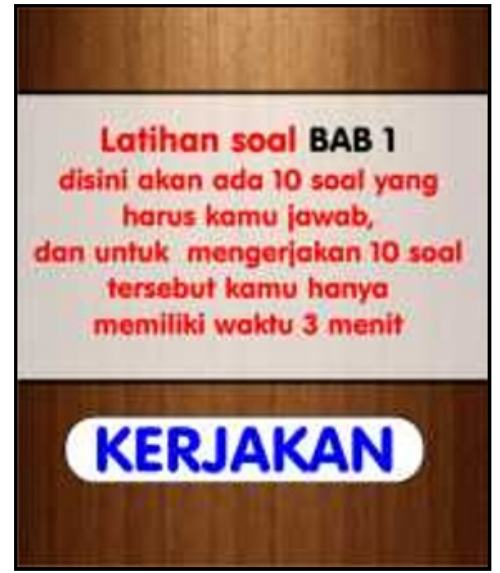

Fig. 12. Display of CHAPTER 1 Exercise

If user presses the work button, the question will be displayed. The time to do the questions is given for 3 minutes (180 seconds) as in Fig. 13.

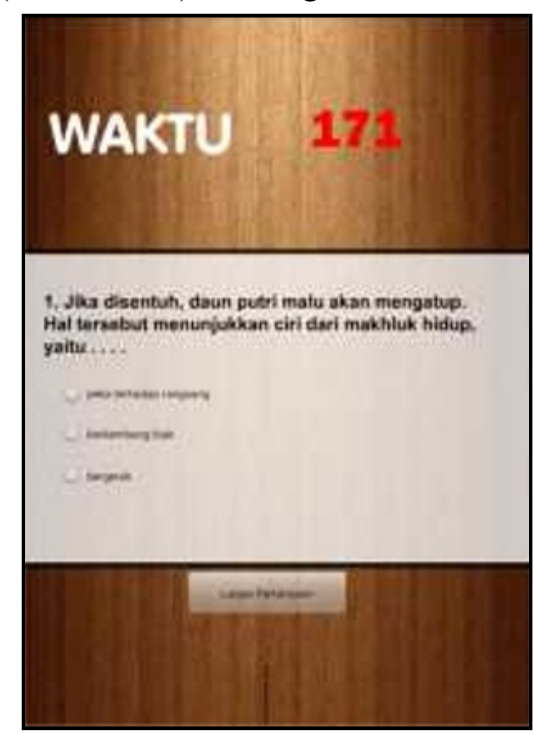

Fig. 13. Display of Exercise Questions
If the user runs out of time when working then the application will automatically display the score of the results of the exercise that has been done (Fig. 14).

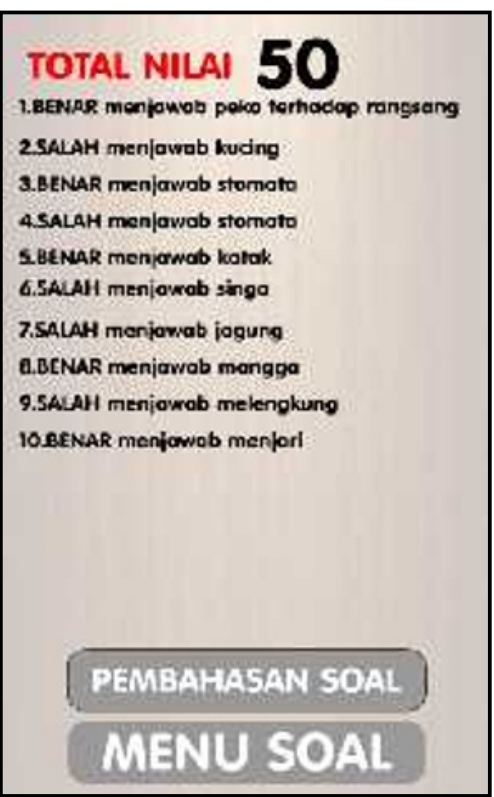

Fig. 14. Score Display

In the score display there is a discussion menu to discuss the questions contained in the practice questions according to the chapter (Fig. 15).

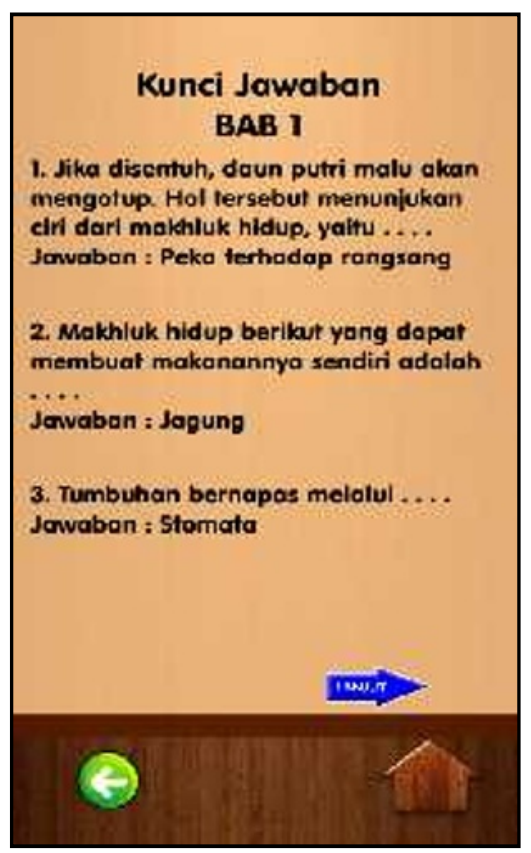

Fig. 15. Discussion of Practice Questions

Game menu is created with the aim of attracting user interest to learn. Besides users can learn, users can play with games that are appropriate for their age also. There are 5 game sub menus in this game menu (Fig. 16). 


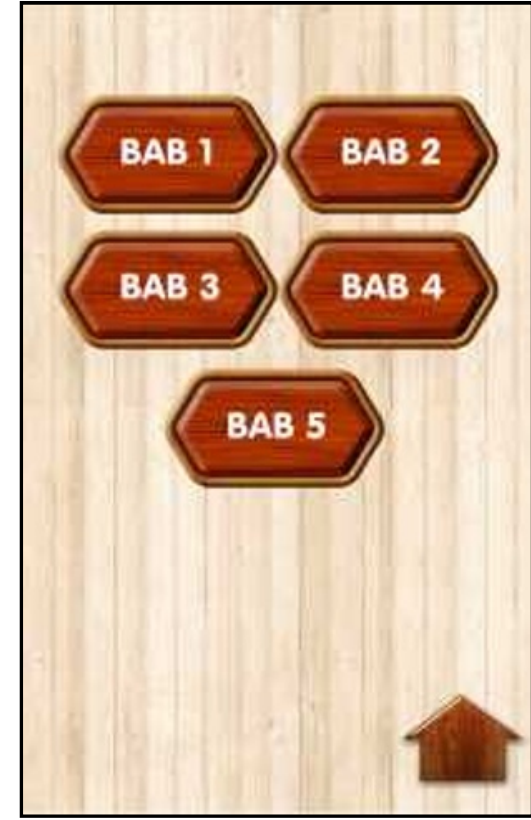

Fig. 16. Game Menu Display

Game 1 is taken from chapter 1 material about living things. The rules of playing game 1 , the user must look for plant-eating animals (Fig. 17).

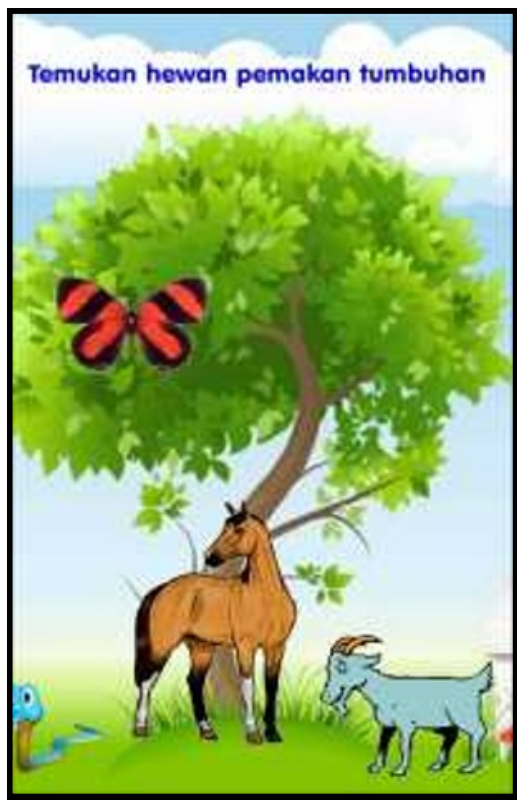

Fig. 17. Game 1 Display

If the user is wrong in choosing the image of the animal then the application will automatically display as in Fig. 18. If the user is correct in choosing the image of the animal then the application will automatically display as in Fig. 19.

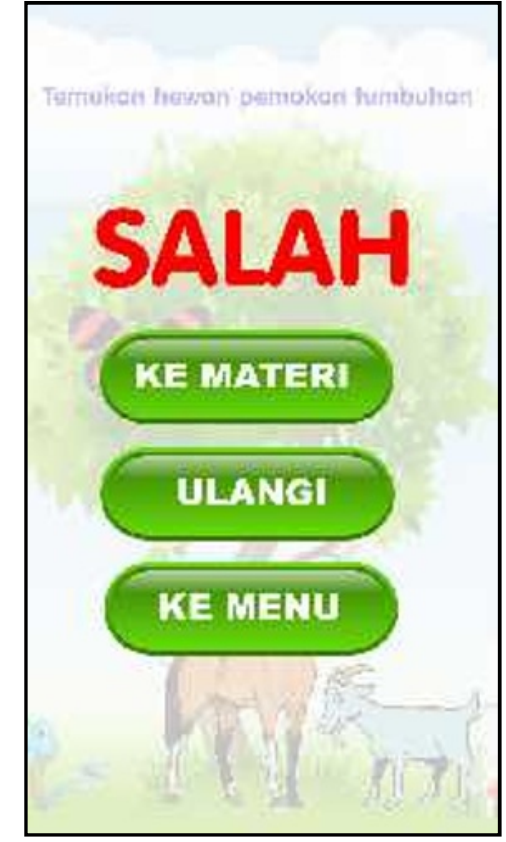

Fig. 18. Wrong Display in Game 1

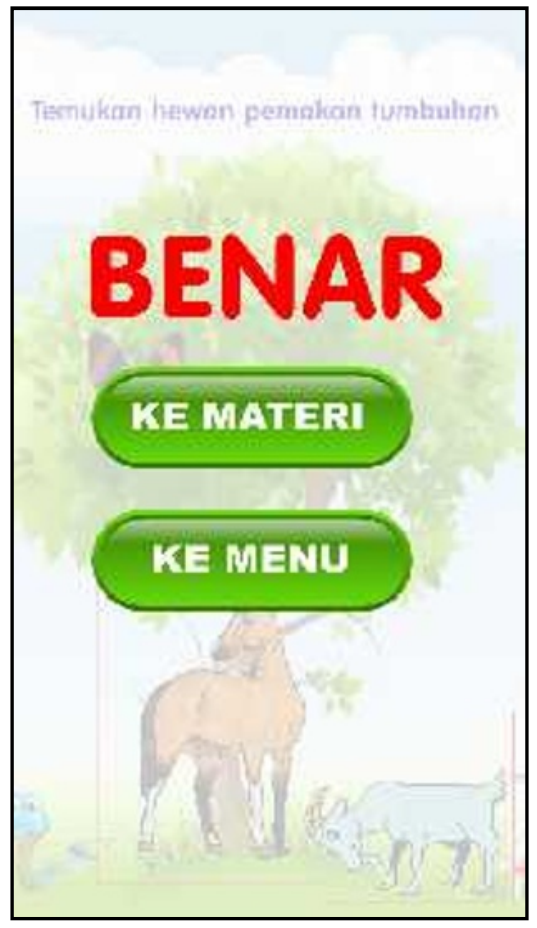

Fig. 19. Right Display in Game 1

Game 2 is taken from CHAPTER 2 material that is about changes in living things. In the game 2 users must move animal images according to the method of breeding. Furthermore, game 3 was taken from CHAPTER 3, which is about the environment. In the game 3 users have to throw garbage in its place by moving the garbage image to the trash can. Meanwhile, game 4 was taken from the CHAPTER 4 material about the object and its nature. In game 4 the user must choose the object that is the writing instrument. The last game, game 5, was taken from CHAPTER 5 about changes in the nature of objects. In this game 5 the user must move 
the image according to the way it changes its nature. In each game, if the user succeeds in playing it, information will be displayed "SUCCESSFUL" ("BERHASIL") and vice versa will be displayed "FALSE" ("SALAH") if the user incorrectly plays it.

\subsection{System Testing}

The system that has been built is tested using the blackbox method to the functions that are in the application that is by running each menu and buttons to see if there are errors or not. Based on the test results on each menu and button, it is stated that there is no error in the application.

\subsection{Measurement of Student Learning Achievement}

Student achievement after using this learning media is presented in Table 1. The number of students who were sampled in this study was 9 students.

Table 1. Results of student learning achievement.

\begin{tabular}{|c|c|c|}
\hline No. & Score Before & Score After \\
\hline 1 & 6 & 6 \\
\hline 2 & 7 & 8 \\
\hline 3 & 7 & 8 \\
\hline 4 & 8 & 8.5 \\
\hline 5 & 8 & 8.5 \\
\hline 6 & 8 & 8.5 \\
\hline 7 & 8 & 8.5 \\
\hline 8 & 8 & 8.5 \\
\hline 9 & 8 & 8.5 \\
\hline
\end{tabular}

Based on the data in Table 1, a correlation analysis was carried out on the two research variables, namely the students' scores before using the learning media and after using the learning media (Table 2) and the analysis using the t-test to determine the average differences of the two research variables.

Table 2. Font styles for a reference to a journal article.

\begin{tabular}{|c|c|c|c|c|}
\hline & & $\mathbf{N}$ & Correlation & Sig. \\
\hline Pair 1 & Pre \& Post & 9 & .932 & .000 \\
\hline
\end{tabular}

Correlation test results in Table 2 for 2 paired samples obtained a significance of 0.00 (smaller than $\alpha=$ 0.05 ). This shows that the two research variables namely the value of students before and after using learning media have a strong correlation of 0.932 . In addition, the results of the analysis using the t-test showed that the two study variables had a significant average difference at the level of $\alpha=5 \%$. Bu using SPSS software shows that the average score of students after using learning media is higher than before using learning media. Overall the achievement of students' scores in the science subject descriptively before using the application has an average value of $7.56 \pm 0.726$ and after using the learning media application rose to $8.11 \pm 0.821$.

\section{CONCLUSION}

The conclusion of this study is to use Android-based learning media applications on subjects of Natural Sciences for elementary school class III can provide solutions to optimize student learning processes. This is evidenced by the increase in value for students after using the application which is an increase of $7.275 \%$.

\section{References}

[1] Hamruni, Strategi Pembelajaran. Yogyakarta: Insan Madani, 2013.

[2] A. Arsyad, "Media pembelajaran." Jakarta: PT Raja Grafindo Persada, 2011.

[3] I. Ibrahim and S. Syaodih, Perencanaan Pembelajaran. Jakarta: Rineka Cipta, 2013.

[4] Moedjiono, "Tantangan dan Peluang Teknologi Informasi dan Komunikasi dalam Peningkatan Kesejahteraan Masyarakat Indonesia," $J$. Atmaluhur, vol. 1, no. 2, pp. 2-8, 2014.

[5] Darmawan, Pendidikan Teknologi Informasi dan Komunikasi. Bandung: Rosda Karya, 2013.

[6] Depdiknas, Naskah Akademik Kajian Kebijakan Kurikulum Mata Pelajaran TIK. Jakarta: Depdiknas, 2013.

[7] Sutarman, Pengantar Teknologi Informasi. Jakarta: Bumi Aksara, 2013.

[8] Supriyanto, Pengantar Teknologi Informasi. Jakarta: Salemba Infotek, 2014.

[9] UNESCO, "ICT Transforming Education: A Regional Guide," 2015. [Online]. Available: http://www.unesco.org/ new/ en/ communicationand-information/ resources/ publications- andcommunication-materials/publications/full-list/icttransforming-education-a-regional-guide/. [Accessed: 04-Jun-2017].

[10] Prasetyaningsih, "Pengembangan Media Pembelajaran IPA Berbasis Adobe Flash CS5 untuk Siswa Kelas V Sekolah Dasar," Universitas PGRI Yogyakarta, 2015.

[11] I. Iswahyudi and U. Urbani, "Pembuatan Media Pembelajaran Ilmu Pengetahuan Alam Kelas 5 Sekolah Dasar Negeri Dagen 1 Jateng," in Prosiding Seminar Riset Unggulan Nasional Informatika dan Komputer FTI UNSA 2013, ISSN: 2302-1136. Volume 2, No. 1, Maret 2013, 2013.

[12] Sutopo, "Mobile Multimedia Development: Flash Mobile Game with MySQL Database," Int. J. Comput. Theory Eng., vol. 5, no. 1, pp. 47-54, 2013.

[13] I. Shah and M. Khan, "Impact of Multimedia-aided Teaching on Students' Academic Achievement and Attitude at Elementary," US-China Educ. Rev. A, vol. 5, no. 5, pp. 349-360, 2015.

[14] H. Mustafidah and Nurhidayah, "Rancangbangun Multimedia Pembelajaran Ilmu Tajwid Guna 
Peningkatan Pemahaman Cara Membaca AlQur'an," JUITA (Jurnal Inform., vol. 1, no. 2, pp. 31-37, 2010.

[15] L. A. Purwanto, H. Mustafidah, and D. K. Hakim, "Pengembangan Media Pembelajaran Matematika Geometri Bangun Ruang Sisi Lengkung Berbasis Multimedia Guna Meningkatkan Minat dan Prestasi Siswa SMPN 1 Patikraja," in Prosiding Seminar Nasional dan Call for Paper "Inovasi Teknologi Ramah Lingkungan dalam Perspektif Pemanasan Global”, 31 Maret 2012, 2012.

[16] H. Mustafidah and N. Kurniasih, "Pengembangan Media Pembelajaran Berbasis Komputer Guna Meningkatkan Pemahaman Mahasiswa pada Mata Kuliah Metode Numerik," BIOMATH, vol. X, no. 1, pp. 1-11, 2009.

[17] H. Mustafidah and D. Ariyanto, "Pengembangan Media Pembelajaran Digital Interaktif Kalkulus-II dalam Peningkatan Prestasi Belajar Mahasiswa," Techno, vol. 11, no. 2, pp. 84-93, 2010.

[18] E. Setyaningsih and H. Mustafidah, "Pengembangan Media Pembelajaran Berbasis Komputer pada Pokok Bahasan Himpunan Guna Meningkatkan Pemahaman Mahasiswa," JUITA (Jurnal Inform., vol. 1, no. 2, pp. 45-51, 2010.

[19] Dalacosta, "Multimedia application with animated cartoons for teaching science in elementary education," J. Comput. Educ. Arch., vol. 52, no. 4, pp. 741-748, 2009.

[20] I. Binanto, Multimedia Digital - Dasar Teori dan Pengembangannya. Yogyakarta: ANDI, 2014.

[21] Safaat, Pemrograman Aplikasi Mobile Smartphone dan Tables PC Berbasis Android. Bandung: Informatika, 2014

[22] Winarto, Membuat Aplikasi Android untuk Pemula. Jakarta: Kompas Gramedia, 2013.

[23] Utami, Kupas Tuntas Android dari Nol Sampai Bisa. Jakarta: Gudang Ilmu, 2014.

[24] Permana, Penuntun Praktis Adobe Photoshop 7.0. Jakarta: Elex Media Komputindo, 2013.

[25] Madcoms, Mahir dalam 7 Hari Macromedia Flash Pro 8. Jakarta: Gramedia, 2013.

[26] Anggra, Pembuatan Game berbasis Flash. Yogyakarta: Gava Media, 2013.

[27] Ariesto, Animasi dengan Macromedia Flash + Action Script. Jakarta: Salemba Empat, 2013.

[28] G. Booch, J. Rumbaugh, and I. Jacobson, The Unified Modeling Language User Guide, 2nd ed. Canada: Addison-Wesley Professional, 2005.

[29] M. F. Rentor, "Rancang Bangun Perangkat Lunak Pengenalan Motif Batik Berbasis Augmented Reality." UAJY, 2013.

[30] M. Shalahuddin and S. Rosa, Modul Pembelajaran Rekayasa Perangkat Lunak. Bandung: Modula, 2013. 